\title{
Sustaining Biodiversity and Income against Climate Change through Food Value Chain System by the Small-Holder Farmers in Southern Nigeria
}

\author{
Asadu Charles Livinus Anija \\ University of Nigeria, Department of Soil Science, PhD, Professor, Nigeria
}

\begin{abstract}
Biodiversity and sustainable income are very necessary in ecosystem stability. The food value chain (FVC) introduced in Nigeria to transform agriculture is commendable because through the system farmers receive various incentives as highly subsidized inputs from government and loans of low interest rates from designated Agricultural Banks and Central Bank. However, the system encourages specialization in the production of the reference crops but intercropping and mixed cropping systems practiced by most small-holder farmers because of its inherent advantages is de-emphasized or completely abandoned. This paper presents the results of two surveys of sole pepper and maize growers in 2015 and 2016 respectively as affected by sudden stoppage of rainfall in Nsukka area. The analyses showed that on the average $>70 \%$ of the pepper farmers lost $\approx 65 \%$ of their pepper fields while $\approx 57 \%$ of the maize fields were lost. For a substitute intercropping system, plantain yield data from plantain plus moringa intercrop trials carried out in 2014 and 2015 were analyzed and projected to incorporate a food crop within inter-alleys. The mean plantain yields from the trials were $20 \mathrm{~kg} \mathrm{plant}^{-1}$ for fresh bunch and 7 suckers stand ${ }^{-1}$. Based on a $6 \mathrm{~m} \mathrm{x}$ $5 \mathrm{~m}\left(\approx 330\right.$ plants $\left.\mathrm{ha}^{-1}\right)$ spacing and the 2016 prices of bunches and suckers, these yields translated to a minimum net income per annum of N 1320000.00 ( $N 330000.00$ from bunches and N 990000.00 from 6 suckers (net) stand ${ }^{-1}$ ). Proceeds from the food crop, moringa seed and leaf extracts used as liquid fertilizer took care of the cost of other inputs and cultural practices. The inter-row spacing of $6 \mathrm{~m}$ allows mechanical cultivation of any food crop by the farmer. This system was considered a reliable insurance against climate change and pest insurgence and can be adopted by farmers in the entire southern Nigeria because both plantain and moringa can do very well in the subregion.
\end{abstract}

Keywords: intercropping; climate change; food security.

\section{UDC 631.5}

DOI: http://dx.doi.org/10.22178/pos.16-9

\section{LCC Subject Category: SB1-1110}

\section{Introduction}

A network of stakeholders involved in growing, processing and selling the food that consumers eat - from farm to table constitutes the food value chain for that particular crop. Thus this comprise the producers, processors, distributors, and consumers as well as governments, nongovernmental organizations (NGOs) and regulators that monitor and regulate the entire food value chain from producer to consumer [5]. The food value chain introduced in Nigeria to transform agriculture was aimed at waging the war against food insecurity arising from the surging population increase. The food value chain system encourages specialization in the production of a particular crop by a farmer which does not favour biodiversity. The traditional small-holder farmers in Nigeria generally produce more than one crop and in most cases add some animals e.g. poultry, goat and/or sheep but at a small scale also. It is well known that over $70 \%$ small holder farmers in Southeastern Nigeria produce their crops in mixtures $[1,12]$.

The latest statistics [8] indicates that the contribution of agriculture to the GDP in Nigeria is $23 \%$, to non-oil exports earnings is $75 \%$ and $70 \%$ of the labor force is in agriculture but agriculture's share of Federal budget is $\approx 2.0 \%$ only. The report recognizes that Nigeria is facing two key gaps in agriculture today: an inability to meet domestic food requirements and an inability to export at quality levels required for market success. The former problem is a productivity challenge driven by an input system and farming model that is largely inefficient [8]. Putting Nigeria's agriculture sector on a path to growth will 
require actions to solve these two gaps: produce enough fresh, high quality foods for the Nigerian market; and serve the export market successfully and earn foreign exchange [8]. It has, however, been argued that food insecurity being orchestrated in Nigeria is man-made [4]. The present Agricultural Promotion Policy (APP) which is building on the successes of Agricultural Transformation Agenda (ATA) is plausible as a lot of the guiding principles of the APP are "carryovers from ATA reflecting the desire for policy stability" [8].

Agricultural financing is critical for producers of all sizes (from small-holder farmers, medium size farmer and larger commercial farms) as well as to properly-functioning input supply markets, processors and traders [8]. However, smallholder farming system from where currently the bulk of the food in Nigeria is produced appeared not to be properly captured in both the ATA and APP food production guides yet their number is the highest when private sector farmers are considered. Both ATA and APP emphasize that agriculture should be private sector driven but $70 \%$ of the labor force in Nigeria is in agriculture and most of these farmers are small-holder farmers. Limited investment and low productivity of small-medium scale producers and the private sector/ investors are due to poor access to land, finance, fertilizers and low soil fertility in Nigeria [8] and this will worsen as specialization in producing a specific crop or animal is a requirement for getting support from the government under the food value chain programme.

Plantain is a major staple food in Africa, Latin America, and Asia. Four African countries have the highest per capita consumption of banana/plantain in the world, with Uganda having the highest. They provide food security and income for small-scale farmers who represent the majority of the producers [9].

According [7] Moringa oleifera is a fast growing tree native to South Asia and now found throughout the tropics. It is sometimes described as the "miracle tree", "drumstick tree", or "horseradish" tree because of its health and agricultural uses. The ratio of moringa extract to water should be 1:30 when used as a liquid fertilizer. To attain the maximum yield of most crops, the dilution can be used as the best foliar applicator to enhance yield because the extract is rich in NPK along with other wonder nutrients and trace minerals. Again moringa leaf extract applied on the crops does not harm bees, wasps and butterflies but helps to control all other pests even rodents [7].

Climate change is one of the major concerns nowadays as agricultural crop production is most vulnerable to these changes since any change in climate translates to change in weather which is an important factor in agriculture [10]. Periodic sudden cessation of rain and inconsistent occurrence of August break in the month of August in southern Nigeria often results to crop failure and the poor performance of second season crops especially maize [2]. The implication of the current agricultural agenda is that researches on intercropping should be refocused to ensure biodiversity and food security against climate change.

This paper analyzed the value of plantain plus moringa mixed alley intercropped with food value chain crop as an alternative intercropping system that can promote crop production where the small-holder farmers can guard against climate change effects and complete loss of income and in addition promote biodiversity, stable income and prevent unexpected crop failure arising from climate change and thus enhance food security.

\section{Materials and Methods}

Location of the study. Nsukka is located by Lat. 060 52'N, Long. 070 24'E within the derived savanna zone of Eastern Nigerian. It is on an average elevation of $447 \mathrm{~m}$ above sea level. It has two seasons namely the rainy and the dry seasons. The former lasts from April to October with a short break (August Break) in the month of August. Average annual rainfall is about $1550 \mathrm{~mm}$ and more than $85 \%$ of this rain falls within the rainy season. The average minimum and maximum temperatures are about 22 and $30{ }^{\circ} \mathrm{C}$ respectively while the average relative humility is rarely below $60 \%$ [2]. The soil was formed from the residua of false-bedded sandstone and has been classified by [3] as Rhodic Kandustalf (Haplic Lixisol). Nsukka location meets the biophysical requirement for the growth of most tree and arable crops including plantain and moringa [11].

Field trials and survey. Plantain plus moringa mixture trial. In 2013 tall (3.2-3.6 m) high yielding plantain variety (Musa spp) from existing plantation at the UNN farm was selected. The selection 
was from a stock that the characteristic of producing two bunches per stand and suitable for intercropping. Four suckers each constituted a replicate in the mini-plot giving a total of twelve stands for the three replicates arranged in alley of four stands. They were planted in holes $30 \mathrm{~cm}$ long x $30 \mathrm{~cm}$ wide x $50 \mathrm{~cm}$ deep and spaced $3 \mathrm{~m}$ intra-alley by $4 \mathrm{~m}$ inter-alley. These were purposely done to accommodate planting of yams that use moringa stands as life stakes. Before placing the suckers in the holes, cured $2 \mathrm{~kg}$ of pig dung was introduced into each of the holes and then covered with earth up to $25 \mathrm{~cm}$ after sucker placement. Planting was done in June, This followed farmers' practice in the area. Again weeding, earth- mulching and staking were done according to farmers' practice. Six stands of plantain labeled 1-6 at the central rows and columns were used for data collection. Fresh bunch yields and the number of suckers of mature saleable size were recorded in August 2014 and 2015. The data were used to estimate the expected value of the plantain in the plantain plus moringa mixed alley system for small-holder farmers for possible introduction of food crops.

Two field surveys were carried out in April-May 2015 and May-June 2016. They were based on the information on the effects of sudden cessation of rainfall on pepper and stem borer attack on maize respectively.
For the survey on pepper, three locations in Nsukka Local Government areas namely Odoru Nsukka, Lejja and Ede-Oballa were purposively selected as they are known for the production of Nsukka yellow pepper known as "Ose Nsukka". Ten fields were selected in each location and their owners were interviewed. With simple questionnaires, data on their age, education, experience in pepper farming and extent of the loss due to the short drought were obtained.

The survey done for early maize was to capture the effect of outbreak of stem borers due to a sudden break in rainfall. The study was done at the University of Nigeria (UNN), Nru Nsukka, Obukpa and Ede-Oballa. The proportion of the fields visited that was damaged by the borers was estimated visually and ranged from 10 to 20 .

\section{Results and discussion}

Table 1 shows the characteristics of the pepper farmers while Table 2 presents the colossal losses of pepper and maize encountered by the farmers in Nsukka area in 2015/2016. These were clearly associated with unexpected drought and stem borer attack.

Table 1 - Effect of sudden drought on pepper at Nsukka in 2015 obtained from ten farmers in each location

\begin{tabular}{|l|l|r|r|r|r|}
\hline \multirow{3}{*}{ Location } & Statistics & \multicolumn{3}{|c|}{ Farmer's Background } & \multirow{2}{*}{$\begin{array}{c}\text { Loss to drought } \\
\text { (\% of entire holding) }\end{array}$} \\
\cline { 3 - 6 } & Age (yrs) & $\begin{array}{c}\text { Education } \\
\text { (yrs in school) }\end{array}$ & Experience in farming (yrs) & $45-95$ \\
\hline \multirow{3}{*}{ Ede-Oballa } & Range & $30-56$ & $6-12$ & $3-8$ & 75.6 \\
\cline { 2 - 6 } & Mean & 42.3 & 6.5 & 5.2 & 34.5 \\
\cline { 2 - 6 } & Cv (\%) & 28.6 & 42.7 & 32.8 & $35-65$ \\
\hline \multirow{3}{*}{ Odoru-Nsukka } & Range & $35-57$ & $6-30$ & $2-12$ & 57.8 \\
\cline { 2 - 6 } & Mean & 46.5 & 12.4 & 8.8 & 23.6 \\
\cline { 2 - 6 } & Cv (\%) & 24.8 & 38.5 & 41.4 & $50-75$ \\
\hline \multirow{3}{*}{ Lejja } & Range & $31-60$ & $6-18$ & $5-10$ & 65.2 \\
\cline { 2 - 6 } & Mean & 47.8 & 9.1 & 8.4 & 35.1 \\
\cline { 2 - 6 } & Cv (\%) & 27.3 & 24.7 & 20.4 & \\
& & & &
\end{tabular}

In the case of pepper farmers, from the Table 1, it is clear that all of the farmers are of age (average $\geq 42$ yrs), fairly educated (average $\geq 7$ yrs in school) and experienced (average $\geq 5$ yrs in pepper farming) so that the issue of negligence was not the cause of the losses. One of the farmers who could not muster courage because he lost over $90 \%$ of his entire holding was reported to have committed suicide at Ede-Oballa location.
From Table 2, stem borer attack was sporadic and it came before tassling and spread fast affecting most of the fields in the area visited. Most of the farmers interviewed informally applied all sorts of insecticides including furadan but they appeared to be ineffective. Even at UNN, fields owned by the fourth year industrial training students of the Faculty of Agriculture were among the hardest hit (Figure 1). Climate change is one 
of the major concerns nowadays as agricultural crop production is most vulnerable to these changes since any change in climate translates to change in weather which is an important factor in agriculture [10].

Table 2 - Proportion of maize field of over 40\% stem borer attack in Nsukka in May/June 2016

\begin{tabular}{|l|c|c|}
\hline \multicolumn{1}{|c|}{ Location } & Number of fields visited & Proportion of attacked (\%) \\
\hline UNN farms & 15 & 60 \\
\hline Nru (common boundary with UNN) & 20 & 45 \\
\hline Obukpa (common boundary with UNN) & 12 & 52 \\
\hline Ede-Oballa (four km south of UNN) & 10 & 56 \\
\hline Mean & 14.2 & 56.7 \\
\hline
\end{tabular}

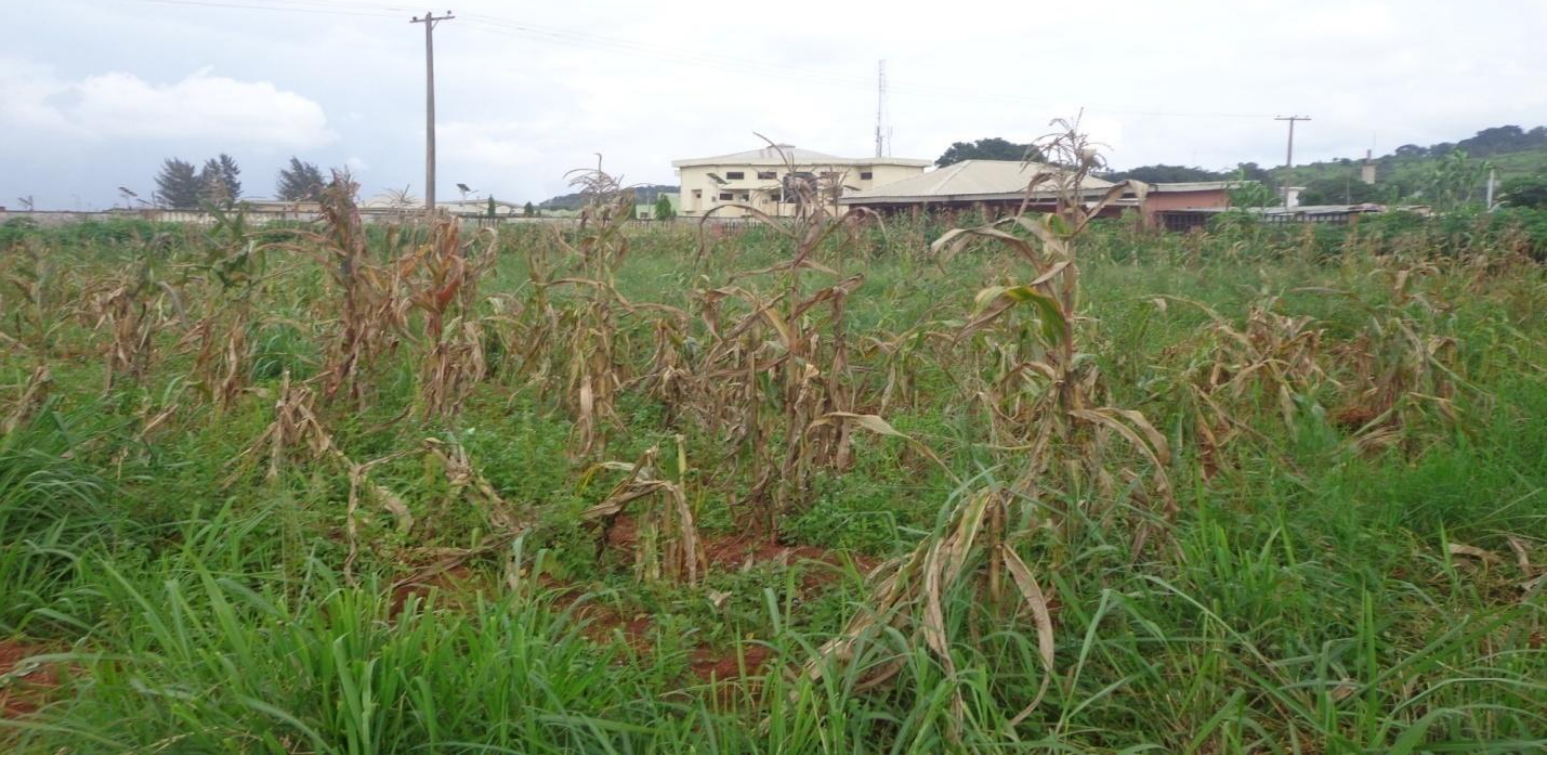

Figure 1 - Abandoned maize field seriously hit by stem borer at UNN

Weather also controls the outbreak of diseases. C. Asadu [2] has shown that one of the major constraints frustrating second season maize cropping in Nsukka is the break in rainfall within the "August Break" because there was always outbreak of stem borers.

A plantain plus moringa alley intra-row mixture would serve as alternative to insurance against total crop failure associated with climate variation and pest insurgence from the results of a mini-plot trials (Tables 3). This would also meet the crop production specialization requirements the food value chain.

From the mini-plot trial an average of $20 \mathrm{~kg}$ fresh bunch of plantain per plant was obtained for the 2 yrs (Table 3 ).

Only one of the six stands (No 4) produced two bunches 2015 (Table 3, Figure 2) with a total bunch weight of $\approx 31 \mathrm{~kg}$.It was the highest yield that year and that was $\approx 56 \%$ above the overall average yield of $20 \mathrm{~kg} \mathrm{stand}^{-1}$ showing that double bunch has overriding advantage over single bunch yield.

Table 3 - Plantain fresh bunch yield and Yield of Plantain suckers at Nsukka in 2014 and 2015

\begin{tabular}{|c|c|c|c|c|}
\hline \multirow[t]{2}{*}{$\begin{array}{l}\text { Plant } \\
\text { No. }\end{array}$} & \multicolumn{2}{|c|}{$\begin{array}{l}\text { Plantain fresh bunch } \\
\text { yield at Nsukka in } \\
2014 \text { and } 2015, \\
\left.\text { (kg plant }^{-1}\right)\end{array}$} & \multicolumn{2}{|c|}{$\begin{array}{l}\text { Yield of Plantain suck- } \\
\text { ers at Nsukka in } 2014 \\
\text { and } 2015 \text { (No plant }{ }^{-1} \text { ) }\end{array}$} \\
\hline & 2014 & 2015 & 2014 & 2015 \\
\hline 1 & 22.5 & 20.5 & 4 & 6 \\
\hline 2 & 12.8 & 16.8 & 6 & 5 \\
\hline 3 & 15.6 & 14.6 & 7 & 8 \\
\hline 4 & 24.2 & 31.2 & 8 & 9 \\
\hline 5 & 23.1 & 23.1 & 5 & 6 \\
\hline 6 & 20.4 & 15.4 & 7 & 8 \\
\hline Mean & 19.8 & 20.3 & 6.2 & 7.0 \\
\hline $\mathrm{Cv}(\%)$ & 23.1 & 15.6 & 23.7 & 22.3 \\
\hline
\end{tabular}

However, the production of two bunches by one stand was noted to inconsistent even from the observations in the current year (2016) data. 
The number of suckers ranged from 4 to 9 suckers per plant with a mean for the two years of $\approx 7$ suckers plant ${ }^{-1}$ (Table 3 ). Plate 3 shows a plant stand with nine suckers in 2015. Sucker production is also a money yielding business in the area.

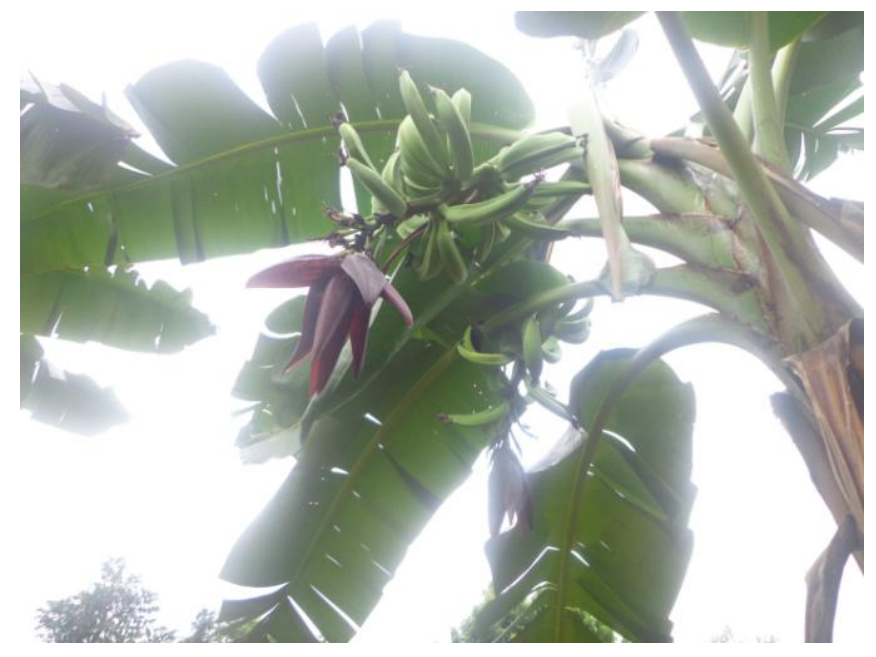

Figure 2 - A single stand of plantain with two bunches at Nsukka

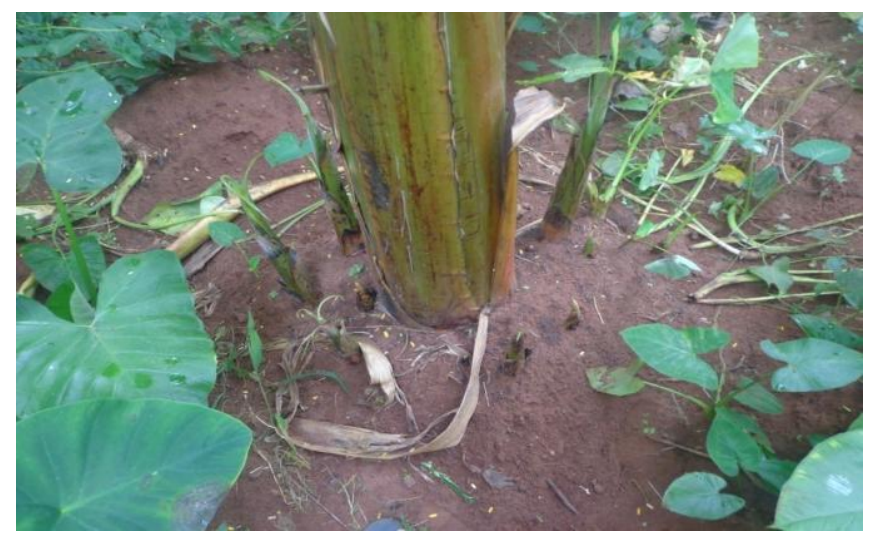

Figure 3 - Plantain stand with nine suckers in 2015 indicating how prolific the stand was

From market information obtained from two Nsukka markets, the price per bunch ranged from N 500.00 to N 2000.00 with a mean of about N 1000.00; that of suckers ranged from N 350 to N 1000 with a mean of about N 500.00. Considering the mean number of suckers 6 per plant (7 less one sucker used for planting) this translated to approximately N 3, 000 per stand per year.

The spacing of $5 \mathrm{~m} \times 6 \mathrm{~m}$ would accommodate the tractor movement between the inter-row alleys but gives a plant population $\approx 330$ of plantain stands per hectare. From the results of the mini-plot trials above, a farmer could realize
N 990000.00 per year from suckers and N 330000.00 from sale of bunches giving a total of N 1320000.00 per annum from plantain alone. This was considered the minimum net profit as the other input costs would be less than proceeds from both the food crop and moringa seeds and leaf extracts. The data on the food value chain crop were not presented because the proceeds would far exceed the cost of other inputs and it is well known that the efficiency of crop mixtures often far exceed that of sole cropping $[4,6]$. Other advantages from the system are derivable from the joint weed and pest control for both the food value chain and plantain; contribution of moringa as a legume in nitrogen fixation as well as the health benefits of moringa seeds [7]; the insurance against crop failure associated with climate change and pest attack as well as compliance with food value chain requirements. Plantain plus moringa alley cropping is highly suitable for the entire southern Nigeria because the normal climatic variables required by plantain according to [11] namely: annual rainfall of $1000-3000 \mathrm{~mm}$; temperature of 27$35^{\circ} \mathrm{C}$; dry months of 3-7 months/yrs are what prevail in the subregion. Moringa and its extracts can provide organic and all-natural alternative to the harmful chemicals for crops, gardens, and lawns ensuring amazing increase in yield and quality of product with a great soil quality even after harvesting and making the planet green [7]. Therefore, plantain plus moringa intra-row alley spacing of $5 \mathrm{~m}$ and inter-row spacing of $6 \mathrm{~m}$ is recommended for the small-holder farms of southern Nigeria so as to accommodate the food value chain of the APP agenda.

\section{Conclusion}

The prevailing traditional mixed cropping system by the small holder farmers that form greater proportion of the food producers in southern $\mathrm{Ni}$ geria could have plantain + moringa alley intercropped food value chain as an alternative system. This system insures against total crop failure and income loss associated with climate change and also encourages biodiversity which is necessary for sustainable environment. Evidence of climate change effects devastating pepper and maize crops were presented to affirm the need for the farmers not to "carry all their eggs in one basket" in order to ensure food security. 


\section{References}

1. Asadu, C. L. A. (1989). A comparative study and evaluation of yam-zone soils and the performance of six cultivars of white yam (D. rotundata) in Southeastern Nigeria (Doctoral thesis). Nsukka: University of Nigeria.

2. Asadu, C. L. A. (2002). Fluctuations in the characteristics of an important short tropical season, 'august break' in Eastern Nigeria. Discovery and Innovation, 14(1), 92-101.

3. Asadu, C. L. A., A.G.O. Dixon and S. C. Eze. 2014. Evaluation of cassava-based systems for adaptation to climatic variations in eastern Nigeria. Agro-Science, 13(2), 37-42.

4. Asadu, C. L. A., Ucheagwu, H., \& Asadu, A. N. (2012.). The reality of man-made food insecurity in Nigeria: A comprehensive analysis. Ibadan: University of Nigeria Press Ltd.

5. Deloitte. (2013). The food value chain. A challenge for the next century. Retrieved from https://www2.deloitte.com/content/dam/Deloitte/global/Documents/ConsumerBusiness/dttl_cb_Food\%20Value\%20Chain_Global\%20POV.pdf

6. Dixon, A. G. O., \& Asadu, C. L. A. (2001). Performance of seven crop combinations in two soils of different land-use history in eastern Nigeria. Agro-Science Journal, 2(2), 70-80.

7. Mercola, J. (2015). The many uses of the mighty moringa tree. Retrieved from http://wakeupworld.com/2015/09/19/the-many-uses-of-the-mighty-moringa-tree

8. Federal Ministry of Agriculture and Rural Development. (2016). The Agriculture Promotion Policy (2016-2020). Retrieved from http://fmard.gov.ng/wp-content/uploads/2016/03/2016-NigeriaAgric-Sector-Policy-Roadmap_June-15-2016_Final.pdf

9. International Institute of Tropical Agriculture. (2016). Banana \& Plantain. Retrieved November 2, 2016, from http://www.iita.org/banana-and-plantain

10. Lansigan, F. P., \& Salvacion, A. R. (2016). Assessing the Effect of Climate Change on Rice and Corn Yields in Selected Provinces in the Philippines. Agricultural Review, New Developments in Agriculture. Academia. Institute of Statistics, University of the Philippines, Los.

11. National Horticultural Research Institute. (2016). Cropping systems with Plantain/Banana in Nigeria. Retrieved from http://banana-networks.org/innovateplantain/files/2013/11/2_presentation-NIGERIA.pdf

12. Okorji, E. C. (1986). Productivity of yam under alternative cropping systems adopted by smallholder farmers of southeastern Nigeria. Agricultural Systems, 22(3), 231-241. doi: 10.1016/0308$521 X(86) 90127-7$

(C) C. L. A. Asadu 


\title{
Поддержка биологического разнообразия и доходности малых фермерских хозяйств в Южной Нигерии с применением системы пищевой ценности в изменяющихся климатических условиях
}

\author{
Asadu Charles Livinus Anija \\ University of Nigeria, Department of Soil Science, PhD, Professor, Нигерия
}

\begin{abstract}
Аннотация. Биоразнообразие и устойчивый доход имеют важное значение в стабильности экосистемы. Цепочка добавленной стоимости продуктов питания, введенная в Нигерии для трансформации сельского хозяйства, заслуживает высокой оценки, так как через данную систему фермеры получают различные стимулы, такие как высокосубсидируемые вклады со стороны правительства и кредиты с низкими процентными ставками от целевых сельскохозяйственных банков и Центрального банка. Несмотря на то, что система поощряет специализацию в производстве эталонных культур, междурядные и смешанные системы возделывания сельскохозяйственных культур, практикуемые большинством мелких фермеров из-за присущих им преимуществ, являются ослабленными или же от них полностью отказываются. В данной статье представлены результаты опросов двух производителей перца и кукурузы в 2015 и 2016 годах соответственно, как пострадавших от внезапного прекращения дождей в районе Nsukka. Анализы показали, что в среднем > 70\% фермеров, выращивающих перец, потеряли $\approx 65 \%$ своих полей, в то время только $\approx 57 \%$ полей кукурузы были потеряны. Для замены системы промежуточных культур, были проанализированы данные урожайности подорожника при пробном междурядном выращивании подорожника и культуры moringa в 2014 и 2015 годах. Было запланировано применить междурядное выращивание данной продовольственной культуры. Средний выход урожайности подорожника при испытании составил 20 кг растений-1 для пучка зелени и 7 боковых отростков ${ }^{-1}$. На основании расчетов при интервале высаживания $6 \mathrm{M}$ х $5 \mathrm{~m}$ ( 330 растения га $\left.{ }^{-1}\right)$ и цен на свежие пучки и отростки в 2016 году был определен минимальный чистый доход в год от N 1320000.00 (N 330000.00 от пучков и N 990000.00 от 6 отростков (нетто). Доходы от продовольственных культур, семян moringa и экстрактов из листьев, используемых в качестве жидкого удобрения, покрыли стоимость других расходов и культурных практик. Междурядье в 6 м позволяет механическое культивирование фермером любой пищевой культуры. Эта система считается надежным страхованием от изменения климата и борьбы с вредителями и может применяться фермерами во всей южной части Нигерии, потому что и подорожник и moringa могут давать хорошую урожайность в этом субрегионе.
\end{abstract}

Ключевые слова: междурядное выращивание; климатические изменения; продовольственная безопасность.

УДК 631.5

LCC Subject Category: SB1-1110

DOI: http://dx.doi.org/10.22178/pos.16-9

(C) C. L. A. Asadu

Статья получена 12.11.2016, принята 28.11.2016, опубликована оnline 30.11.2016 